antigenic stimulus (or both) is the subject of further investigation.

The tropical splenomegaly syndrome or "big spleen disease" of Uganda may be considered as a reactive "lymphoreticular proliferative disorder." The lymphocyte increase is usually confined to the hepatic sinusoids and to the spleen; plasma cells may be present in both organs but are more common in the spleen. Occasionally cases also show an increase of "lymphocytes in the upper abdominal lymph nodes (Hutt and Muivah, 1969), in the marrow, and in the blood (Watson-Williams and Allan, 1968). There is some evidence that this "reactive" proliferation of lymphocytes may become neoplastic, with resultant chronic lymphatic leukaemia (Watson-Williams et al., 1967 ; Lowenthal and Hutt, 1968). Associated with the increase of immunologically competent cells, lymphocytes and plasma cells, in the spleen and liver there is an increase of fixed phagocytic cells (Kupffer cells and splenic histiocytes). Despite this pronounced lymphoreticular proliferation, however, no defect in immunological function was noted in this study.

We wish to thank Professor W. Parson and Dr. J. B. Wood, Department of Medicine, Makerere University College Medical School, for referral of patients for study. Thanks are also due to Drs. Richard H. Morrow, J. M. S. Luyombya, Mary Herald, LeRoy Fass, and Christina Templeton for assistance in the clinical care of the patients, and to Mrs. S. Waymark, Mrs. Mary Proctor, Miss Eleanor Stashick,k, and Mr. J. M. Wamboka for technical assistance. Dr. Paul P. Carbone aided greatly in the conception of the study and in the preparation of the manuscript.
REFERENCES

Brown, R. S., Haynes, H. A., Foley, H. T., Godwin, H. A., Berard, C. W., and Carbone, P. P. (1967). Annals of Internal Medicine, 67, 291.

Charmot, G., and Vargues, R. (1963). Semaine des Hôpitaux de Paris, 39, 1421 .

Fahey, J. L., and McKelvey, E. M. (1965). fournal of Immunology, $94,84$.

Gebbie, D. A. M. Hamilton, P. J. S., Hutt, M. S. R., Marsden, P. D. Voller, A., and Wilks, N. E. (1964). Lancet, 2, 392.

Hamilton, P. J. S., Gebbie, D. A. M., Hutt, M. S. R., Lothe, F., and Wilks, N. E. (1966). British Medical fournal, 2, 548.

Hamilton, P. J. S., Hutt, M. S. R., Wilks, N. E., Olweny, C., Ndawula, R. L., and Mwanje, L. (1965). East African Medical fournal, 42, 191 .

Hamilton, P. J. S., et al. (1969). Lancet, 2, 109.

Hutt, M. S. R., and Muivah, P. M. (1969). Unpublished observations.

Landy, M. and Lamb, E. (1953). Proceedings of the Society of Experimental Biology and Medicine, 82, 593.

Lowenthal, M. N., and Hutt, M. S. R. (1968). East African Medical Fournal, 45, 100.

Marsden, P. D., Connor, D. H., Voller, A., Kelly, A., Schofield, F. D. and Hutt, M. S. R. (1967). Bulletin of the World Health Organization, 36, 901.

Marsden, P. D., et al. (1965). British Medical fournal, 1, 89.

Pitney, W. R. (1968). Transactions of the Royal Society of Tropical Medicine and Hygiene, 62, 717.

Pryor, D. S. (1967). Quarterly fournal of Medicine, 36, 321.

Shaper, A. G., Kaplan, M. H., Mody, N. J., and McIntyre, P. A. (1968) Lancet, 1, 1342

Trincão, C., Dos Santos Nascimento, J., and Cordeiro Ferreira, N. (1966) Acta Haematologica, 36, 26.

Watson-Williams, E. J., and Allan, N. C. (1968). British Medical fournal, 4, 793.

Watson-Williams, E. J., Allan, N. C., and Fleming, A. F. (1967). British Medical fournal, 4, 416.

Wells, J. V. (1967). Medical fournal of Australia, 2, 777.

\title{
Blood Glucose and Insulin Relationships in the Human Mother and Fetus before Onset of Labour
}

\author{
T. M. COLTART,* M.B., PH.D. ; R. W. BEARD, $\dagger$ M.B., M.R.C.o.G. \\ R. C. TURNER, $\ddagger$ M.B., M.R.C.P. ; N. W. OAKLEY,§ M.B., M.R.C.P.
}

British Medical fournal, 1969, 4, 17-19

\begin{abstract}
Summary: The effects of a maternal intravenous glucose load on the fetal plasma levels of glucose and insulin have been studied in 11 patients before the onset of labour. Within five minutes the fetal plasma glucose concentration rose significantly, indicating a rapid transfer of glucose across the placenta. Following this, the rate of fall in fetal plasma glucose closely reflected that in the mother.
\end{abstract}

Serial fetal insulin estimations carried out in 8 of the 11 subjects following maternal glucose showed an early rise in fetal insulin in four and a delayed rise in one; in the remaining three there was no definite change.

It is concluded that the blood glucose level of the fetus is controlled by that of the mother, but that the fetal pancreas at term may respond to hyperglycaemia by the secretion of insulin.

\section{Introduction}

Glucose rapidly crosses the placenta in the presence of a concentration gradient between mother and fetus, but serial
- recordings of simultaneous fetal and maternal blood glucose levels have seldom been made under conditions of a rapidly altering maternal glucose concentration. Although it is known that the human fetal pancreas contains insulin from the twelfth week of intrauterine life (Steinke and Driscoll, 1965) the extent to which fetal beta cells are capable of responding to metabolic stimuli is uncertain.

\section{Methods}

Eleven patients gave informed consent to participate in the investigation. Ten were induced for postmaturity at $\mathbf{4 2}$ weeks' gestation. One patient (E) was thought to have a "small for dates" fetus and was therefore induced at 38 weeks. In this patient insulin results only have been included. Apart from

* Resident Registrar, Chelsea Hospital for Women, London S.W.3 Present address: Department of Obstetrics and Gynaecology, Guy's Hospital, London S.E.1.

+ Senior Lecturer, Department of Obstetrics and Gynaecology, King's College Hospital, London S.E.5.

¥ Leverhulme Research Fellow, Institute of Clinical Research, Middlesex Hospital, London W.1.

$\$$ Senior Registrar, Middlesex Hospital, London W.1. 
these clinical features the pregnancies were uncomplicated. No patient had a family history or clinical evidence of diabetes mellitus. Surgical induction was carried out at 9 a.m. after a 12-hour fast. The patients were sedated with intramuscular pethidine $150 \mathrm{mg}$. and promethazine hydrochloride $50 \mathrm{mg}$. one hour before induction.

After artificial rupture of the membranes a capillary blood sample was obtained from the fetal scalp by a modified Saling (1964) technique and at the same time maternal venous blood was sampled. The mother was then given $50 \mathrm{ml}$. of $50 \mathrm{~g}$./ $100 \mathrm{ml}$. glucose by rapid intravenous injection. Simultaneous maternal venous and fetal capillary blood samples were collected at $5,10,20,30,50,70,90$, and 120 minutes after the intravenous injection. In a control group of three volunteer patients samples were taken at the same time intervals after the intravenous injection of $50 \mathrm{ml}$. of physiological saline. Blood was anticoagulated with heparin and stored as frozen plasma pending analysis. Plasma glucose was estimated by the use of glucose oxidase and orthotolidine in a modification of the autoanalyser technique described by Marks and Lloyd (1963).

Plasma immunoreactive insulin was measured by means of an assay involving charcoal separation of antibody-bound and antibody-free insulin. The sensitivity of the assay (calculated as two standard deviations of the replicates from zero) was $1-2 \mathrm{pg} . / 750 \mu \mathrm{l}$. incubation volume. Fetal insulin was measured in three to six 10- $\mu$ l. aliquots, depending on the quantity of plasma available, with the addition of $40 \mu$ l. of charcoal-treated " insulin-free" human plasma for comparison with a standard curve containing $50 \mu \mathrm{l}$. of the same charcoal-treated plasma. The fetal insulin results were expressed as a mean of the replicates with $95 \%$ confidence limits for each result (estimated as twice the standard error of the mean of the replicates). The human insulin standard used was Eli Lilly 516-734b-33. Our batch of insulin standard subsequently showed slight immunological damage, so that absolute values for plasma insulin may have been overestimated. This, however, does not affect the significance of changes observed during the tests.

Occasional fetal blood samples were haemolysed; instances of this were always recorded, as haemolysis may give rise to spuriously low insulin values.

\section{Results}

\section{Glucose}

The mean fetal and maternal glucose values for the glucosetreated group are shown in the Table. There was no significant difference between the fasting level of glucose in the maternal venous and fetal capillary plasma. Five minutes after receiving $25 \mathrm{~g}$. of glucose intravenously the maternal plasma glucose concentration had risen to a level of $243 \mathrm{mg} . / 100 \mathrm{ml}$. The fetal plasma glucose reached a value of $138 \mathrm{mg} . / 100 \mathrm{ml}$. at five minutes and a peak value of $146 \mathrm{mg} . / 100 \mathrm{ml}$. at 10 minutes after the injection. In the latter part of the test the concentration of glucose in the fetal plasma closely reflected that of the maternal, but at a slightly lower level (Fig. 1). In the saline-treated group there was no significant change in the glucose concentration of either the fetal or the maternal plasma.

Mean Maternal and Mean Fetal Plasma Glucose Responses to the Rapid Administration of $25 \mathrm{~g}$. of Glucose Intravenously to 10 Mothers

\begin{tabular}{|c|c|c|c|c|c|c|c|c|c|}
\hline & \multicolumn{9}{|c|}{ Time (Minutes) } \\
\hline & 0 & 5 & 10 & 20 & 30 & 50 & 70 & 90 & 120 \\
\hline $\begin{array}{c}\text { Maternal glucose } \\
\text { (mg./100 ml.) } \\
\pm \text { I S.D. } \\
\text { No. sampled } \\
\text { Fetal glucose }\end{array}$ & $\begin{array}{l}70 \\
10 \\
10\end{array}$ & $\begin{array}{r}243 \\
30 \\
7\end{array}$ & $\begin{array}{r}195 \\
24 \\
9\end{array}$ & $\begin{array}{r}167 \\
16 \\
10\end{array}$ & $\begin{array}{r}142 \\
15 \\
10\end{array}$ & $\begin{array}{r}107 \\
11 \\
10\end{array}$ & $\begin{array}{l}88 \\
17 \\
10\end{array}$ & $\begin{array}{r}74 \\
9 \\
10\end{array}$ & $\begin{array}{r}57 \\
3 \\
4\end{array}$ \\
\hline $\begin{array}{l}\text { (mg./100 ml.) } \\
\pm \text { I S.D. } \\
\text { No. sampled } \quad \cdots\end{array}$ & $\begin{array}{r}70 \\
9 \\
10\end{array}$ & $\begin{array}{r}138 \\
7 \\
4\end{array}$ & $\begin{array}{r}146 \\
21 \\
10\end{array}$ & $\begin{array}{r}142 \\
17 \\
10\end{array}$ & $\begin{array}{r}122 \\
19 \\
10\end{array}$ & $\begin{array}{l}96 \\
21 \\
10\end{array}$ & $\begin{array}{l}75 \\
17 \\
10\end{array}$ & $\begin{array}{l}63 \\
13 \\
10\end{array}$ & $\begin{array}{r}50 \\
5 \\
4\end{array}$ \\
\hline
\end{tabular}

\section{Insulin}

Plasma insulin assays were undertaken in 8 out of the 11 subjects who received glucose and in the three control subjects. In both groups the fasting fetal insulin levels ranged from 5 to $30 \mu \mathrm{u} . / \mathrm{ml}$. In the glucose-treated group the maternal insulin levels rose to between 80 and $480 \mu \mathrm{u} . / \mathrm{ml}$. Changes in fetal insulin levels in this group are shown in Fig. 2. In four of

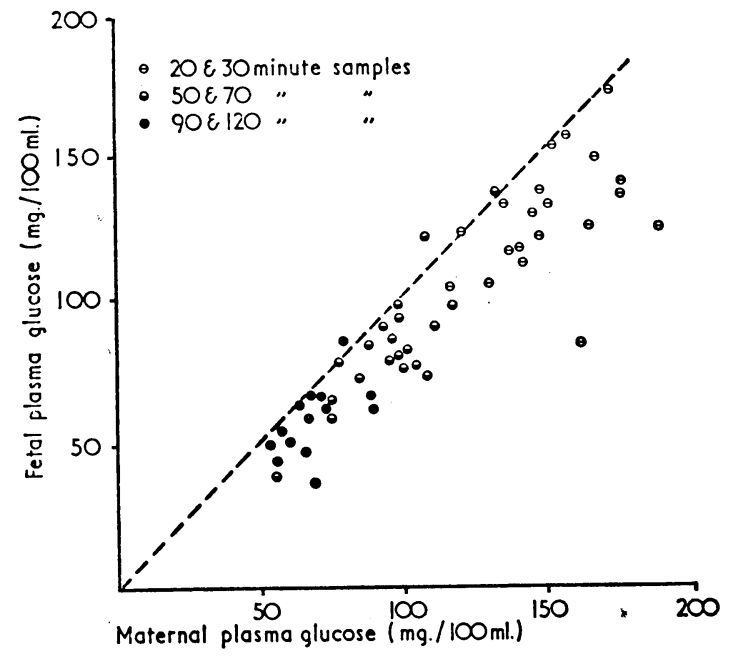

FIG. 1.-Relation between individual maternal and fetal plasma glucose values from 20 to 120 minutes inclusively after rapid administration of $25 \mathrm{~g}$. of glucose intravenously

to the mother. The dotted line represents the $45^{\circ}$ axis.

the eight fetuses (D, E, G, and $H$ ) there was an early rise in insulin five minutes after glucose injection. In one fetus (A) there was a late rise, maximum at 70 minutes, while in one (B) no value departed significantly from the fasting level. In two fetuses ( $C$ and $F$ ) there was either no rise or a small one, distinction between these alternatives being impossible because of haemolysed fasting blood samples.
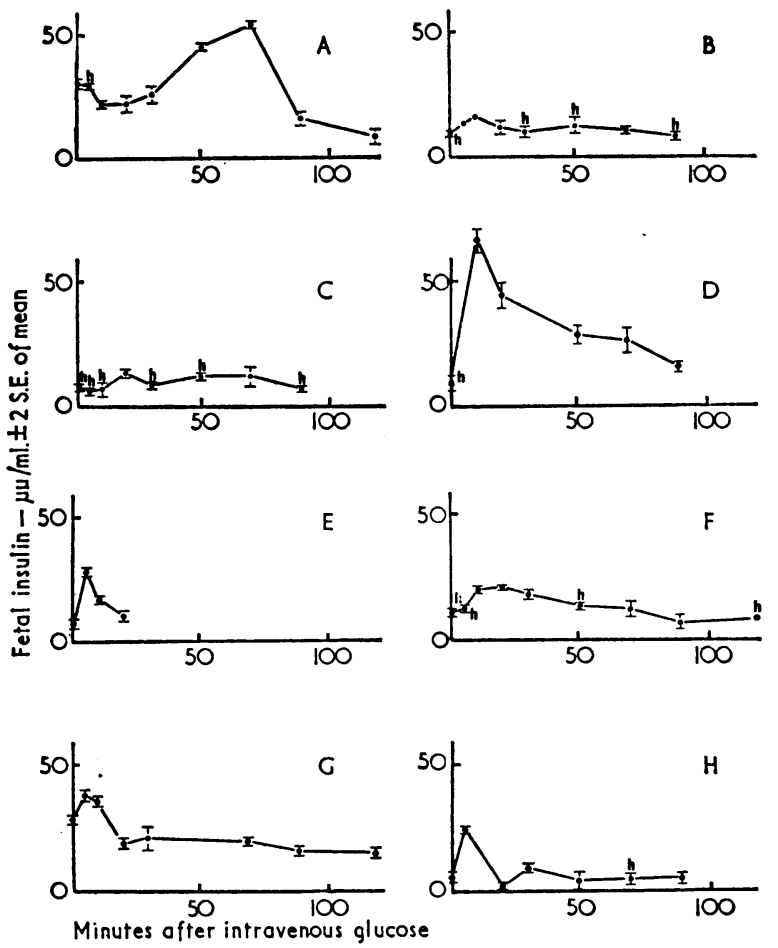

Fic. 2.-Individual fetal plasma insulin patterns observed in the eight subjects studied after the rapid administration of $25 \mathrm{~g}$. intravenously to the mother. Haemolysed samples (h). 
There was no correlation either between the peak levels of maternal and fetal insulin following glucose administration or between the insulin rise in the fetus and the weight of the baby at birth. In the saline-treated group there was no change in the fetal or maternal insulin levels during the tests.

\section{Discussion}

The results of this study indicate that there is a rapid transfer of blood glucose in the human from mother to fetus, and that fetal hyperglycaemia may be associated with a variable increase in the concentration of fetal plasma immunoreactive insulin. Previous workers (Paterson et al., 1967 ; Raivio and Teramo, 1968) have reported a wider gradient at rest between maternal and fetal glucose values than we have observed. The reason for this is not clear, but could involve factors such as the sampling site in both mother and fetus, the estimation of plasma or whole blood glucose, and the timing of the samples in relation to maternal food intake and labour. The present study confirms the view of Whaley et al. (1966) and Paterson et al. (1968) that the fetal level of blood glucose is dependent on that of the mother, and shows more exactly the close relation between the maternal and fetal levels in the presence of a changing maternal glucose concentration. The persistence of a maternalfetal gradient during the latter part of the test period suggests that the fetal tissues are utilizing glucose.

The presence of insulin in umbilical cord blood (Milner and Hales, 1965 ; Thomas et al., 1967), in fetal blood (Adam et al., 1968 ; Paterson et al., 1968), and in neonatal urine (Lowy and Schiff, 1968) indicates that the fetal pancreas secretes insulin. Investigations into the ability of the fetal or neonatal pancreas to secrete insulin in response to hyperglycaemia, however, have led to conflicting results. In fetuses of 14-16 weeks' gestation Adam et al. (1968) observed no plasma insulin response at 5 and 10 minutes after glucose via the umbilical vein. At term Milner and Hales (1965) found higher levels of insulin in cord blood of babies whose mothers had received intravenous glucose during labour than in babies of control mothers. In the neonate Jørgensen et al. (1966) and Spellacy et al. (1967) observed that glucose via the umbilical vein produced delayed insulin response. Grasso ct al. (1968) showed an insulin response to amino-acids. On the other hand, Paterson et al. (1968) found no change in fetal insulin at 15 and 60 minutes after an intravenous glucose load to the mother during labour, and in the neonate Baird and Farquhar (1962) and Stimmler et al. (1964) reported no rise in plasma insulin following glucose administration.

In our study the rise of fetal plasma insulin in four out of the eight fetuses suggested that the fetal pancreas may be responsive to hyperglycaemia at term. The extent and time of onset of the insulin rise was variable, however, and this was apparent only when individual cases were considered. It would seem important, therefore, not to take the mean of the results of different tests or significant variable responses may be overlooked. Results similar to our findings have been reported by Tiernan et al. (1967) and Isles et al. (1968) in neonates before the first feed. There are, however, no satisfactory explanations for the apparently differing patterns of insulin release.

The possibility that a rise in fetal insulin could be due to placental transfer of maternal hormone must be considered. Buse et al. (1962) and Adam et al. (1968) in man, Clark and Soeldner (1967) in the rat, and Cohen et al. (1968) in the sheep have shown little if any transfer. Nevertheless, Gitlin et al.
(1965) and Mintz et al. (1969), using human subjects and monkeys respectively, have proposed that some fetal insulin is of maternal origin. The balance of evidence suggests that if transfer of maternal insulin across the placenta occurs it does so only to a very limited extent, a view that is supported by the absence of any correlation between maternal and fetal levels of plasma insulin in this study.

The role of fetal insulin is open to speculation, and the extent to which it influences carbohydrate utilization in the fetus is as yet unanswered. The close correlation between maternal and fetal concentrations of glucose, occurring at a time when the maternal level is rapidly changing, suggests that the absolute level of glucose in the fetus is dependent on, and is regulated by, the larger glucose pool of the mother. It is possible that in the fetus the primary role of insulin may be to stimulate anabolic pathways rather than to control the blood sugar.

We are grateful to Professor C. J. Dewhurst and the consultant staff of Queen Charlotte's Hospital for allowing us to investigate patients under their care; to Dr. J. D. N. Nabarro for advice and encouragement; to Mr. L. Calodney, Miss C. Knight, and Mrs. G. Maritz for technical assistance ; to the Central Research Fund, University of London, for providing the Technicon AutoAnalyzer used for glucose estimation; and to Miss Seldon and the labour ward staff of Queen Charlotte's Hospital. One of us (R. C. T.) is in tenure of a Leverhulme Research Scholarship. The insulin antiserum was a gift from Dr. Julia Ellis.

\section{REFERENCES}

Adam, P. A., Teramo, K., Raiha, N., Gitlin, D., and Schwartz, R. (1968). Pediatric Research, 2, 399.

Baird, J. D., and Farquhar, J. W. (1962). Lancet, 1, 71.

Buse, M. G., Roberts, W. J., and Buse, J. (1962). fournal of Clinical Investigation, 41, 29.

Clark, C. M., and Soeldner, J. S. (1967). Diabetes, 16, 516.

Cohen, N. M., Alexander, D. P., Britton, H. G., Nixon, D. A., and Parker, R. A. (1968). Diabetalogia, 4, 380.

Gitlin, D., Kumate, J., and Morales, C. (1965). Pediatrics, 35, 65.

Grasso, S., Saporito, N., Messina, A., and Reitano, G. (1968). Lancet, 2, 755 .

Isles, T. E., Dickson, M., and Farquhar, J. W. (1968). Paediatric Research, 2, 198.

Jørgensen, K. R., Deckert, T., Pedersen, L. M., and Pedersen, J. (1966), Acta Endocrinologica, 52, 154.

Lowy, C., and Schiff, D. (1968). Lancet, 1, 225.

Marks, V., and Lloyd, K. (1963). Proceedings of the Association of Clinical Biochemists, 2, 176.

Milner, R. D. G., and Hales, C. N. (1965). British Medical fournal, 1, 284.

Mintz, D. H., Chez, R. A., and Horger, E. O. (1969). Fournal of Clinical Investigation, 48, 176.

Paterson, P., Page, D., Taft, P., Phillips, L., and Wood C. (1968). Fournal of Obstetrics and Gynaecology of the British Commonwealth, 75, 917.

Paterson, P., Phillips, L., and Wood, C. (1967). American fournal of Obstetrics and Gynaecology, 98, 938.

Raivio, K. O., and Teramo, K. (1968). Acta Paediatrica Scandinavica, $57,512$.

Saling, E. (1964). Zeitschrift für Geburtshilfe und Gynäkologie, 162, 56.

Spellacy, W. N., Gall, S. A., and Carlson, K. L. (1967). Obstetrics and Gynecology, 30, 580 .

Steinke, J., and Driscoll, S. G. (1965). Diabetes, 14, 573.

Stimmler, L., Brazie, J. V., and O'Brien, D. (1964). Lancet, 1, 137.

Thomas, K., Gasparo, M. de., and Hoet, J. J. (1967). Diabetologia, 3, 299.

Tiernan, J. R., Kemball, M. L., and Smith, C. A. (1967). Abstracts of the Society of Pediatric Research, p. 169. Whaley, W. H., Zuspan, F. P., and Nelson, G. H. (1966). American
fournal of Obstetrics and Gynecology, 94, 419. 